\title{
An Observational Study of Prevalence and Risk Factors Associated with Peripheral Vascular Disease
}

\author{
Authors \\ Jothiprasad Venkatesan ${ }^{1 *}$, Noufal TB $^{1}$, Venugopal Sarveswaran ${ }^{2}$ \\ ${ }^{1}$ Resident, ${ }^{2}$ Head of the Department \\ Department of General Surgery, Sri Ramakrishna Hospital, Sarojini Naidu Road, Coimbatore, \\ Tamil Nadu, India-641044 \\ *Corresponding Author \\ Jothiprasad Venkatesan
}

\begin{abstract}
Peripheral vascular disease (PVD) is stenosis of arteries supplying other than those in brain and heart. The prevalence of PVD is very high in general practice and it is under-diagnosed most of the times. Simple investigation tool like Ankle Brachial Index (ABI) can be used to screen patients with high risk factors and diagnose the disease in the early phase itself, so that morbidity associated with the disease can be reduced.

Keywords: Peripheral vacslar disease, ABI, Risk factors, Prevalence, Screening.
\end{abstract}

\section{Introduction}

This Peripheral vascular disease (PVD) or peripheral artery occlusive disease is defined as obstruction or deterioration of arteries other than those supplying the heart and those within the brain. It also refers to signs, symptoms or abnormal non invasive tests in one or both legs attributable to obstructive atherosclerotic disease or some other aetiology ${ }^{[1]}$. There are various risk factors associated with the incidence of PVD and it varies from region to region based on population, lifestyle and environmental changes. The major factors associated are gender, age, smoking, hypertension, diabetes mellitus, renal insufficiency, dyslipidemia, morbid obesity etc,. The underlying pathology is the impairment of circulation and resultant ischemia to the end organ involved ${ }^{[2]}$. The prevalence of PVD in primary care practices is high, yet physician awareness of the PVD diagnosis is relatively low. A simple ABI measurement identified a large number of patients with previously unrecognised PVD. Atherosclerosis risk factors were very prevalent in PVD patients, but these patients received less intensive treatment for lipid disorders and hypertension and were prescribed anti-platelet therapy less frequently than were patients with CVD. These results showed that under-diagnosis of PVD in primary care practice may be a barrier to effective secondary prevention of the high ischemic cardiovascular risk associated with PVD. ${ }^{[3]}$

Increased mean levels of low density cholesterol, triglycerides and systolic blood pressure may help to explain the higher prevalence of PVD in diabetic subjects compared with that in normal glucose tolerance subjects. ${ }^{[4]}$ PVD is an important predisposing factor for atherosclerosis, which in 
2010 was estimated to affect more than 202 million people worldwide ${ }^{[5]}$. It affects about $4.3 \%$ of Americans aged 40 years and older, reaching $12.29 \%$ and $29 \%$ in those over 60 and 70 years of age, respectively ${ }^{[6]}$. Mohan et al have reported the prevalence of PVD in South Indian diabetics to be $3.9 \%^{[7]}$; in Western series the prevalence ranges between $22-45 \%{ }^{[8]}$. The prevalence of PVD in diabetics also increases with the duration of diabetes from $15 \%$ to $45 \%$ at 10 to 20 years respectively after the diagnosis of diabetes ${ }^{[9]}$. Hyperglycaemia seems to be a stronger risk factor for $\mathrm{PVD}^{[10]}$. Smokingis also a stronger risk factor for $\mathrm{PVD}^{[11]}$. Increased risk of PVD is also associated with the number and duration of smoking ${ }^{[12]}$. Older age is an important risk factor for PVD in patients with diabetes $^{[13]}$. Novel risk factors like hyperhomocystineamia have also been proposed in the development of $\mathrm{PVD}^{[14]}$. However a majority of PVD patients reports no symptoms. ${ }^{[15] .}$

Hence it is essential to study the risk factors which are commonly associated with PVD in our region and to identify the severity and outcome of these factors. It has become important to identify the disease in its initial stage and to prevent the adverse outcome of the disease by prior screening and proper history eliciting. Encouraging vulnerable patients to avoid the modifiable risk factors which cause adverse outcomes and to lead a disease free survival is our main goal.

\section{Material and Methods}

This was a Cross sectional study with duration from December 2017 to June 2019. Two approaches to sample size was made. One to detect a $45 \%^{[1]}$ prevalence of PVD among adults aged $>40$ years of age, and another to detect an odds ratio of 2.0 with the prevalence of PVD and associated factors. A choice will be made based on clinic attendance, patient and consent given by them during the study period. In order to detect a hospital based prevalence of $45 \%$ with $5 \%$ absolute precision (40\% to $50 \%$ ) and $95 \%$ confidence interval, Sample size $n=\left[N^{*} p(1-p)\right] /\left[\left(d^{2} / Z_{1-\alpha / 2}^{2} *\left((N-1)+p^{*}(1-p)\right)\right]\right.$
Population size (for finite population correction factor or fpc) (N): 100000

Hypothesised \% frequency of outcome factor in the population (p): $45 \%+/-5$

Confidence limits as $\%$ of $100($ absolute $+/-\%)(\mathrm{d})$ : $5 \%$

Sample size $\mathrm{n}=\quad[100000 * 0.45(0.55)] /$
$\left[(0.05)^{2} / 1.96^{2} *(100000-1)+0.45 *(0.55)\right]=379$

For association between prevalence and predisposing factors, with an odds ratio of 2.0 the samples size ${ }^{2}$ required is

The standard normal deviate for $\alpha=Z_{\alpha}=1.960$

The standard normal deviate for $\beta=\mathrm{Z}_{\beta}=0.842$

Pooled proportion $=\mathrm{P}=\left(\mathrm{q}_{1} * \mathrm{P}_{1}\right)+\left(\mathrm{q}_{0} * \mathrm{P}_{0}\right)=0.373$

$\mathrm{A}=\mathrm{Z}_{\alpha} \sqrt{ } \mathrm{P}(1-\mathrm{P})\left(1 / \mathrm{q}^{1}+1 / \mathrm{q}_{0}\right)=1.905$

$\mathrm{B}=\mathrm{Z}_{\beta} \sqrt{ } \mathrm{P}_{1}\left(1-\mathrm{P}_{1}\right)\left(1 / \mathrm{q}_{1}\right)+\mathrm{P}_{0}\left(1-\mathrm{P}_{0}\right)\left(1 / \mathrm{q}_{0}\right)=0.813$

$\mathrm{C}=\left(\mathrm{P}_{1}-\mathrm{P}_{0}\right)^{2}=0.026$

Total group size $=(\mathrm{A}+\mathrm{B})^{2} / \mathrm{C}=283$

\section{Inclusion Criteria}

All Patients of age $>40$ years who are diagnosed as peripheral vascular disease by $\mathrm{ABI}$

\section{Exclusion Criteria}

- Patients with venous insufficiency and venous ulcers.

- Patient with previous history of autoimmune disease.

- Those who refuse to be a part of the study.

\section{Methodology}

After getting consent, all patients of age $>40$ years will be screened by ankle brachial index. Those who are diagnosed to have peripheral vascular disease will be examined clinically after taking a detailed history. A questionnaire will be asked to the patient. Finally a master chart will be made by which various risk will be assessed statistically.

A total of 537 were screened during December 2017 to June 2019, for PVD using ankle branchial index. Prevalence with 95\% confidence interval (with normal approximation) was calculated. All positive cases (n-130) and 282 negative for PVD, where history and complete laboratory tests were available was included for risk factor analysis. 


\section{Results}

Figure 1 Ankle Brachial Index values among those

Screened

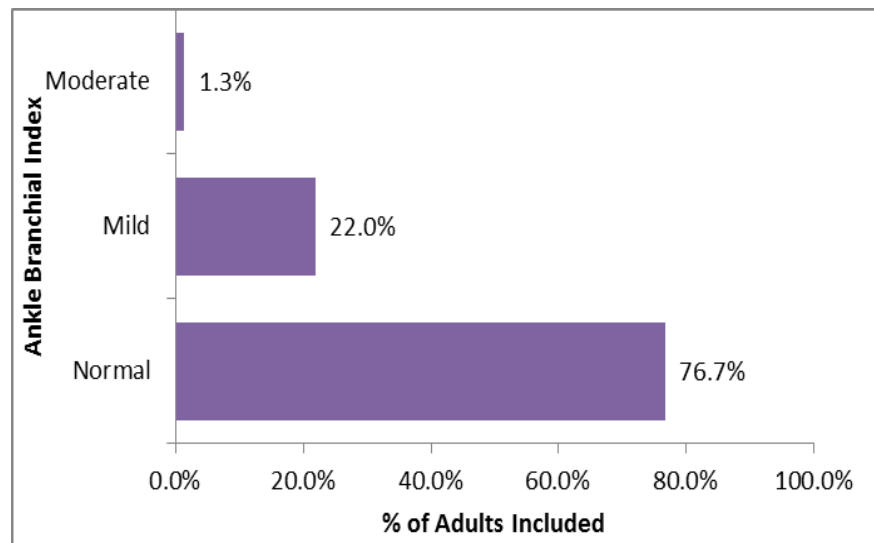

ABI was done for all of the 537 adults screened. Classification of an adults as having PVD was done based on $\mathrm{ABI}<0.9$. Based on this definition, the number of adults classified as positive for PVD was 130. Out of this, about one-fifth (22.0\%, n-121) were categorised as having mild and $9(1.3 \%)$ as moderate.

Figure 2 Prevalence of Peripheral Vascular Disease

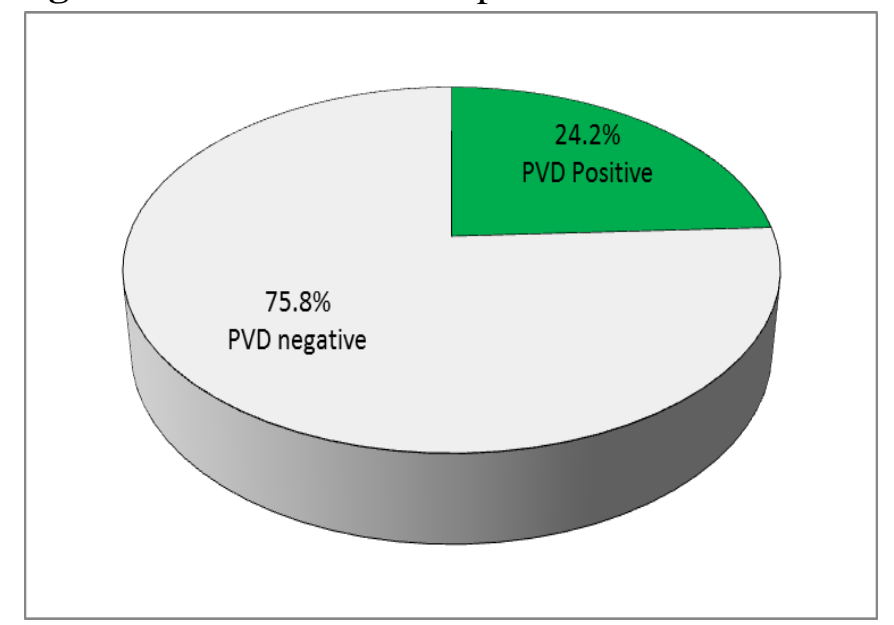

Prevalence of PVD among adults $>40$ years of age attending a general surgery department is $24.2 \%$ [95\% CI: 20.6, 27.8].
Figure 3 Age and Sex Distribution

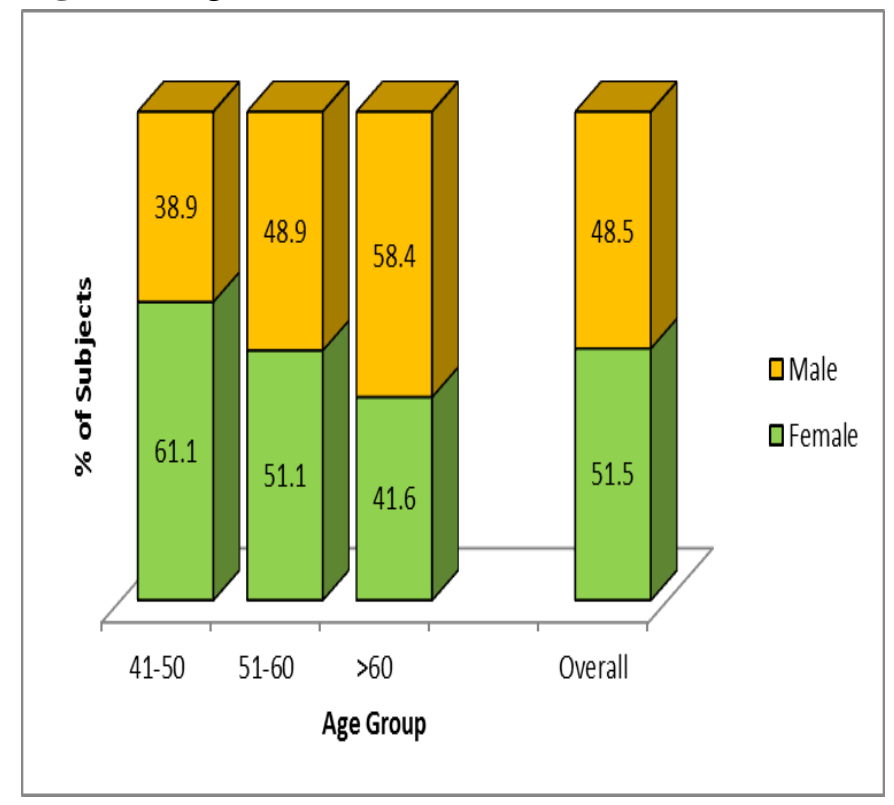

The subjects were aged 56.2 \pm 8.8 years ranging from 41 to 94 years. There were more number of adults in the 51-60 (45.5\%) years age group compared to $41-50(28.8 \%)$ and those aged $>60$ years $(25.8 \%)$. The graph depicts that- about $58.4 \%$ of male over 60 years of age were having PVD (Figure3).

Figure 4 Presentation of Systemic illness \& Symptoms of the Adults in the Study

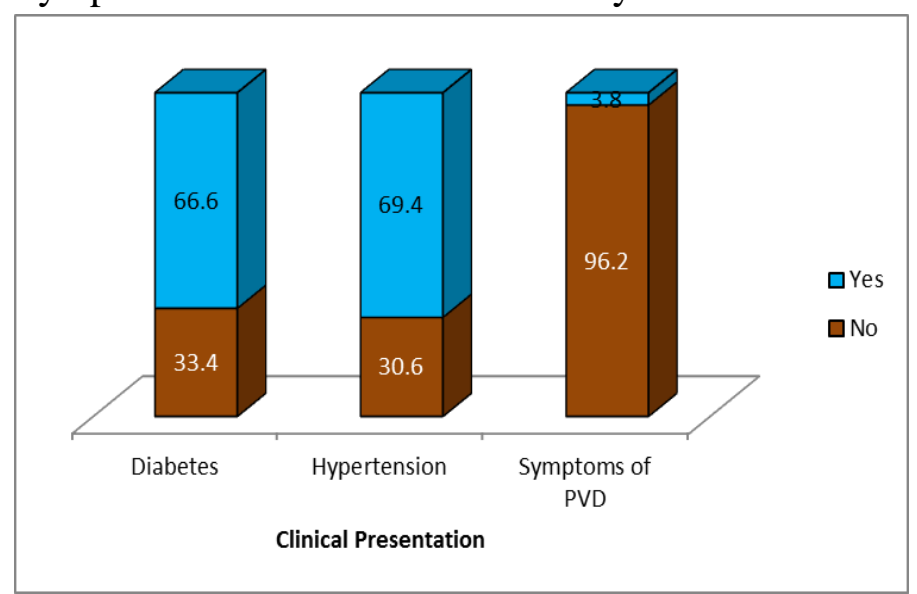

Two-thirds $(66.6 \%, \mathrm{n}-261)$ of the adults reported of having diabetes during the time of screening. Similarly, a significant $(69.4 \%)$ proportion reported hypertension during history taking. Almost all (96.2\%) were asymptomatic to PVD (Figure4). 
Table 1 Smoking and PVD

\begin{tabular}{|c|c|c|c|c|}
\hline \multirow[b]{2}{*}{ Smoking } & \multicolumn{2}{|c|}{ PVD } & \multirow[b]{2}{*}{$\mathrm{p}$ value } & \multirow{2}{*}{$\begin{array}{c}\mathrm{OR}[95 \% \\
\mathrm{CI}]\end{array}$} \\
\hline & Absent & Present & & \\
\hline No & $83.5 \%$ & $16.5 \%$ & \multirow{2}{*}{$<0.0001$} & \multirow{2}{*}{$\begin{array}{c}11.2 \\
{[6.8,18.4]}\end{array}$} \\
\hline Yes & $31.2 \%$ & $68.8 \%$ & & \\
\hline
\end{tabular}

An adult reporting of smoking increased (11.2 times) his/her likelihood of being positive for PVD. The proportion of PVD cases among smokers was $68.8 \%$ compared to $16.5 \%$ among non-smokers and the difference was statistically significant $(\mathrm{p}<0.0001)($ Table1).

Table 2 Mean Smoking Pack Years and PVD

\begin{tabular}{|l|c|c|c|c|c|}
\hline \multirow{2}{*}{ PVD } & & \multicolumn{2}{|c|}{ Smoking Pack years } & \multirow{2}{*}{ p value } \\
\cline { 3 - 4 } & $\mathrm{N}$ & Mean & SD & $\begin{array}{c}\text { Absolute } \\
\text { difference }\end{array}$ & \\
\hline Absent & 262 & 1.1 & 2.7 & 8.2 & $<0.0001$ \\
\hline Present & 130 & 9.37 & 7.5 & & \\
\hline
\end{tabular}

The intensity of smoking habit as recorded by mean pack years $(1.1 \pm 2.7)$ was higher by 8 pack years among PVD cases compared to those who were negative for PVD $(9.4 \pm 7.5)$ by ABI (Table2)

Figure 5. Hypertension and Smoking with PVD Prevalence

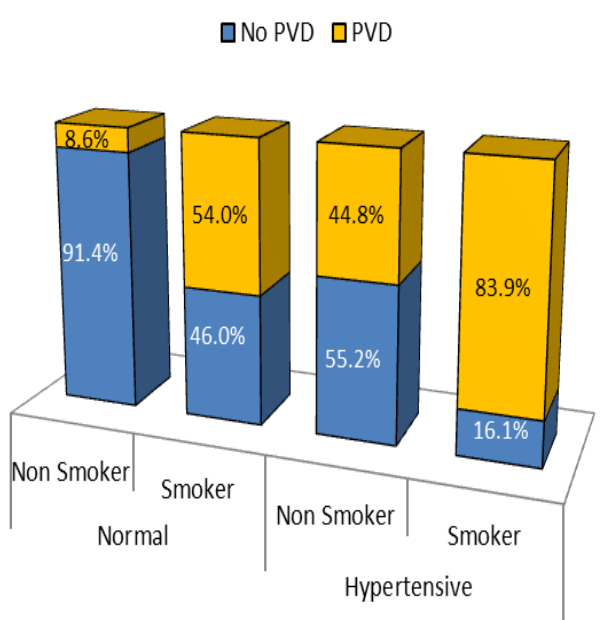

Hypertension and smoking was combined as a variable and was associated with PVD status (Figure 5). Smokers with history of hypertension had the highest prevalence of PVD $83.9 \%$, compared to a mere $8.6 \%$ among non-smokers with no history of hypertension. Compared to a Non Hypertensive Non Smoker, a Non Hypertensive Smoker had 12.4 times and a Hypertensive Smoker had 55.2 times risk of having PVD. There was a statistically significant difference $(p-<0.0001)$ in the PVD proportion between the categories.

Table 3 Laboratory Investigations

\begin{tabular}{|l|c|c|c|c|}
\hline Parameter & Mean & SD & Minimum & Maximum \\
\hline HDL & 34.3 & 5.7 & 24.0 & 64.0 \\
\hline TGL & 158.7 & 37.2 & 84.0 & 302.0 \\
\hline Urea & 23.8 & 5.0 & 17.0 & 54.0 \\
\hline Creatinine & 0.7 & 0.2 & 0.4 & 2.1 \\
\hline
\end{tabular}

Laboratory investigations revealed an average HDL of $34.3 \pm 5.7$ with a maximum of $64.0 \mathrm{mg} / \mathrm{dL}$ (Table3). The triglyceride levels ranged from 84.0 to $32.0 \mathrm{mg} / \mathrm{dL}$ with an average of $158.7 \mathrm{mg} / \mathrm{dL}$. Blood urea was $23.8 \pm 5.0$ with a maximum of 54.0 $\mathrm{mg} / \mathrm{dL}$. Creatinine was $0.7 \pm 0.2 \mathrm{mg} / \mathrm{dL}$ with a maximum of 2.1. C reactive protein was elevated in less than one-fifth $(18.6 \%, \mathrm{n}-73)$ of the adults included. Coronary artery disease was present in 96 $(24.5 \%)$ adults.

Table 4 Age and PVD

\begin{tabular}{|l|l|c|c|c|c|}
\hline \multirow{2}{*}{ PVD } & \multirow{2}{*}{$\mathrm{n}$} & \multicolumn{3}{|c|}{ Age } & \multirow{2}{*}{ p value } \\
\cline { 3 - 4 } & & Mean & $\begin{array}{c}\text { Std. } \\
\text { Deviation }\end{array}$ & $\begin{array}{c}\text { Absolute } \\
\text { difference }\end{array}$ & \\
\hline Absent & 262 & 53.6 & 7.3 & 7.9 & $<0.0001$ \\
\hline Present & 130 & 61.5 & 9.3 & & \\
\hline
\end{tabular}

The mean age of those positive (53.6 \pm 7.3 years) for PVD was higher than those who were negative (Table 4). The absolute difference between the two mean values was about 8 years and the difference was statistically significant $(\mathrm{p}<0.0001)$, suggestive of higher age being a risk factor associated with PVD. 
Table 5 Gender and PVD

\begin{tabular}{|c|c|c|c|c|}
\hline \multirow[b]{2}{*}{ Sex } & \multicolumn{2}{|c|}{ PVD } & \multirow[b]{2}{*}{$\mathrm{p}$ value } & \multirow[b]{2}{*}{ OR $[95 \% \mathrm{CI}]$} \\
\hline & Absent & Present & & \\
\hline Female & $80.2 \%$ & $19.8 \%$ & \multirow{2}{*}{$<0.0001$} & \multirow{2}{*}{$3.6[2.3,5.7]$} \\
\hline Male & $52.6 \%$ & $47.4 \%$ & & \\
\hline
\end{tabular}

There was a marked difference in the proportion of PVD among female adults (19.8\%) compared to their male counterparts $(47.4 \%)$. This statistically significant $(p<0.0001)$ difference in proportion is indicative of men being 3.6 times highly likely to have PVD compared to their women (Table5)

Table 6. History of DM and PVD

\begin{tabular}{|c|c|c|c|c|}
\hline \multirow{2}{*}{$\begin{array}{l}\text { Self } \\
\text { Reported } \\
\text { DM }\end{array}$} & \multicolumn{2}{|c|}{ PVD } & \multirow[b]{2}{*}{$\mathrm{p}$ value } & \multirow[b]{2}{*}{ OR $[95 \% \mathrm{CI}]$} \\
\hline & Absent & Present & & \\
\hline No & $82.4 \%$ & $17.6 \%$ & \multirow{2}{*}{$<0.0001$} & \multirow{2}{*}{$8.4[5.2,13.5]$} \\
\hline Yes & $35.9 \%$ & $64.1 \%$ & & \\
\hline
\end{tabular}

An adult reporting of having history of DM increased (8.4 times) his/her likelihood of being positive for PVD. The proportion of PVD cases among DM cases was $64.4 \%$ compared to $17.6 \%$ among non-DM adults and the difference was statistically significant $(\mathrm{p}<0.0001)$ (Table6).

Table7. History of Hypertension and PVD

\begin{tabular}{|l|c|c|c|c|}
\hline \multirow{2}{*}{$\begin{array}{l}\text { Self- } \\
\text { reported } \\
\text { HT }\end{array}$} & \multicolumn{2}{|c|}{ PVD } & \multirow{4}{*}{} \\
\cline { 2 - 3 } & Absent & Present & p value & OR[95\% CI] \\
\hline No & $80.9 \%$ & $19.1 \%$ & \multirow{2}{*}{$<0.0001$} & $7.9[4.9,12.7]$ \\
\hline Yes & $35.0 \%$ & $65.0 \%$ & & \\
\hline
\end{tabular}

An adult reporting of having history of HT increases (7.9 times) his/her likelihood of being positive for PVD. The proportion of PVD cases among HT cases was $65.0 \%$ compared to $19.1 \%$ among non-DM adults and the difference was statistically significant $(\mathrm{p}<0.0001)$ (Table7).
Table 8. Clinical Symptoms and PVD

\begin{tabular}{|c|c|c|c|c|}
\hline \multirow[b]{2}{*}{ Symptoms } & \multicolumn{2}{|c|}{ PVD } & \multirow[b]{2}{*}{$\mathrm{p}$ value } & \multirow[b]{2}{*}{ OR $[95 \% \mathrm{CI}]$} \\
\hline & Absent & Present & & \\
\hline Present & & $100.0 \%$ & \multirow{2}{*}{$<0.0001$} & \multirow{2}{*}{$\begin{array}{c}70.8 \\
{[4.2,1187.6]}\end{array}$} \\
\hline Absent & $69.5 \%$ & $30.5 \%$ & & \\
\hline
\end{tabular}

Having clinical symptoms such as claudication pain, ulcer or tissue loss, increased the likelihood of having PVD by 70.8 times compared to those who did not show any. There is a statistically significant $(p<0.0001)$ association between presence of symptoms and PVD.

Table 9 BMI and PVD

\begin{tabular}{|l|c|c|c|}
\hline \multirow{2}{*}{ BMI } & \multicolumn{2}{|c|}{ PVD } & \multirow{2}{*}{ p value } \\
\cline { 2 - 3 } & Absent & Present & p \\
\hline$<18.5$ & $100.0 \%$ & & \multirow{2}{*}{$<0.0001$} \\
\hline $18.5-25.0$ & $76.4 \%$ & $23.6 \%$ & \\
\hline$>25$ & $36.2 \%$ & $63.8 \%$ & \\
\hline
\end{tabular}

Figure 6. BMI and PVD

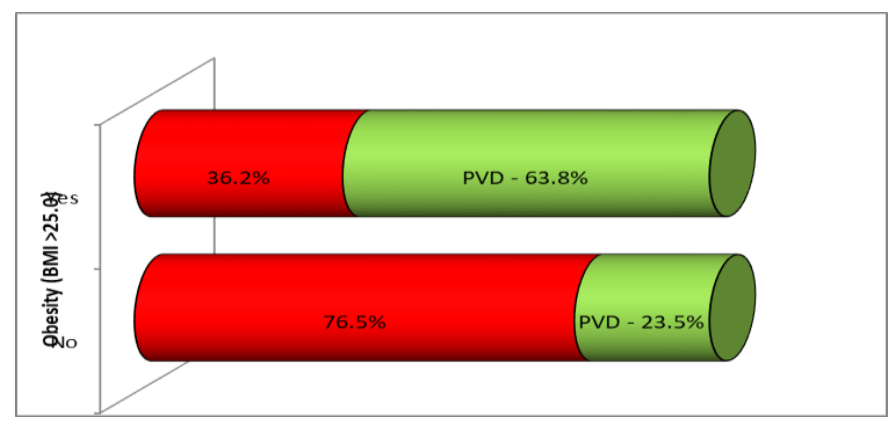

There was a statistically significant difference in the BMI status of an adult and his/her PVD status ( $\mathrm{p}<0.0001)$ (Table9). All adults who had BMI less than 18.5 were negative for PVD, while close to one-fourth $(23.6 \%)$ who were in the $18.5-25.0$ category were positive for PVD. Two-thirds (63.8\%) adults who were obese by having a BMI $>25.0$ were positive for PVD. Those who were obese (BMI>25.0) were 5.7 times more likely to be positive for PVD compared to those whose BMI was $<=25$. 
Table 10 HDL/Triglyceride

\begin{tabular}{|c|c|c|c|c|c|}
\hline Parameter & $\mathrm{n}$ & Mean & SD & $\begin{array}{l}\text { Absolute } \\
\text { difference }\end{array}$ & $\mathrm{p}$ value \\
\hline \multicolumn{6}{|c|}{ HDL } \\
\hline $\begin{array}{l}\text { PVD } \quad- \\
\text { Absent }\end{array}$ & 262 & 35.7 & 6.1 & \multirow{2}{*}{4.2} & \multirow{2}{*}{$<0.0001$} \\
\hline $\begin{array}{l}\text { PVD - } \\
\text { Present }\end{array}$ & 130 & 31.4 & 3.6 & & \\
\hline \multicolumn{6}{|c|}{ Triglyceride } \\
\hline $\begin{array}{l}\text { PVD } \\
\text { Absent }\end{array}$ & 262 & 143.8 & 16.9 & \multirow{2}{*}{44.9} & \multirow{2}{*}{$<0.0001$} \\
\hline $\begin{array}{l}\text { PVD } \\
\text { Present }\end{array}$ & 130 & 188.7 & 47.5 & & \\
\hline
\end{tabular}

Mean HDL was lower (31.4 \pm 3.6$)$ among positive cases compared to those who were negative $(35.7 \pm 6.1)$. There was a difference of $4.2 \mathrm{mg} / \mathrm{dL}$ between the mean values of HDL when compared to those positive for PVD and those that were not (Table 10). The difference in mean HDL being statistically significant $(\mathrm{p}<0.0001)$ suggest low HDL being a risk factor for PVD. Mean TGL was lower (143.8 \pm 16.9$)$ among negative cases compared to those who were positive $(188.7 \pm 47.5)$ for PVD. The difference of $44.9 \mathrm{mg} / \mathrm{dL}$ between the mean TGL values was statistically significant $(p<0.0001)$ suggest high TGL being a risk factor for PVD.

Table11. Renal parameters and PVD

\begin{tabular}{|l|c|c|c|c|c|}
\hline \multicolumn{5}{|l|}{ Blood Urea } \\
\begin{tabular}{|l|c|c|c|c|} 
PVD - \\
Absent
\end{tabular} & 262 & 21.5 & 2.2 & & \\
\hline $\begin{array}{l}\text { PVD - } \\
\text { Present }\end{array}$ & 130 & 28.5 & 5.7 & & $<0.0001$ \\
\hline Creatinine & & & \\
\hline $\begin{array}{l}\text { PVD - } \\
\text { Absent }\end{array}$ & 262 & 0.7 & 0.1 & \multirow{2}{*}{0.1} & $<0.0001$ \\
\hline $\begin{array}{l}\text { PVD - } \\
\text { Present }\end{array}$ & 130 & 0.8 & 0.2 & & \\
\hline
\end{tabular}

Mean blood urea was lower (21.5 \pm 2.2$)$ among negative cases compared to those who were positive (28.5 \pm 5.7$)$ for PVD. There was a difference of 6.9 $\mathrm{mg} / \mathrm{dL}$ between the mean values of blood urea when compared to those positive for PVD and those that were not (Table11). The difference in mean blood urea being statistically significant $(\mathrm{p}<0.0001)$. Mean creatinine value was slightly higher $(0.8 \pm 0.2)$ among positive cases compared to those who were negative $(0.7 \pm 0.1)$. The difference in mean creatinine values was statistically significant $(\mathrm{p}<0.0001)$.

Table 12 CRP and PVD

\begin{tabular}{|c|c|c|c|c|}
\hline \multirow{2}{*}{$\begin{array}{l}\mathrm{C} \text { reactive } \\
\text { Protein }\end{array}$} & \multicolumn{2}{|l|}{ PVD } & \multirow[b]{2}{*}{$\mathrm{p}$ value } & \multirow[t]{2}{*}{ OR $[95 \% \mathrm{CI}]$} \\
\hline & Absent & Present & & \\
\hline Elevated & $21.9 \%$ & $78.1 \%$ & \multirow{2}{*}{$<0.0001$} & \multirow{2}{*}{$12.0[6.5,22.1]$} \\
\hline Normal & $77.1 \%$ & $22.9 \%$ & & \\
\hline
\end{tabular}

A laboratory report suggesting elevated c reactive protein increases (12.0 times) an adult's likelihood of being positive for PVD. The proportion of PVD cases among elevated c reactive protein cases was $78.1 \%$ compared to $22.9 \%$ among normal adults and the difference was statistically significant $(\mathrm{p}<0.0001)($ Table12).

Figure7. CAD and PVD

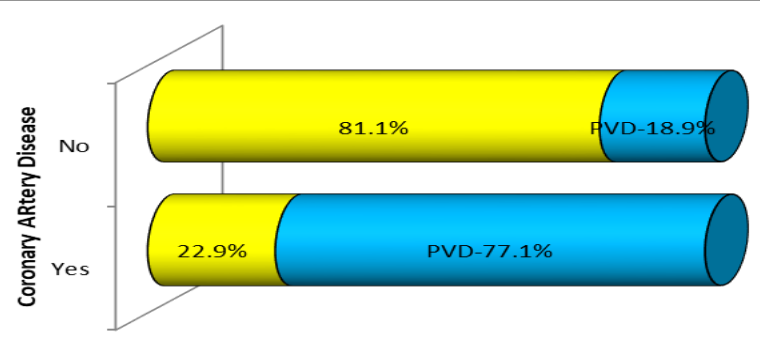

A laboratory report suggesting CAD increases (14.4 times) an adult's likelihood of being positive for PVD. The proportion of PVD cases among CAD patients cases was $77.1 \%$ compared to $18.9 \%$ among normal adults and the difference was statistically significant $(\mathrm{p}<0.0001)$ (Figure7). 
Table13. Multivariate Logistic Regression Analysis of Perivascular Disease Status with Demographic, Lifestyle choices and Laboratory Parameters

\begin{tabular}{|c|c|c|c|c|}
\hline \multirow[b]{2}{*}{ Independent Variables } & \multirow[b]{2}{*}{$\begin{array}{l}\text { Odds } \\
\text { Ratio }\end{array}$} & \multicolumn{2}{|c|}{$\begin{array}{l}95.0 \% \text { C.I. for } \\
\text { OR }\end{array}$} & \multirow[b]{2}{*}{$\mathrm{p}$ value } \\
\hline & & $\begin{array}{l}\text { Lower } \\
\text { Limit }\end{array}$ & $\begin{array}{l}\text { Upper } \\
\text { Limit }\end{array}$ & \\
\hline Age & 1.1 & 1.01 & 1.3 & 0.023 \\
\hline \multicolumn{5}{|l|}{ Diabetes } \\
\hline No & 1.0 & & & \multirow[b]{2}{*}{0.003} \\
\hline Yes & 12.8 & 2.4 & 69.2 & \\
\hline \multicolumn{5}{|l|}{ Hypertension*Smoking } \\
\hline No HT No Smoker & 1.0 & & & \multirow{4}{*}{0.001} \\
\hline No HT Smoker & 14.0 & 1.6 & 125.8 & \\
\hline HT Smoker & 54.5 & 5.6 & 533.5 & \\
\hline HT Non Smoker & 42.7 & 3.9 & 463.9 & \\
\hline \multicolumn{5}{|l|}{ Obesity } \\
\hline No & 1.0 & & & \multirow[b]{2}{*}{0.015} \\
\hline Yes & 10.3 & 1.6 & 66.7 & \\
\hline HDL & 0.8 & 0.7 & 0.97 & 0.024 \\
\hline TGL & 1.1 & 1.0 & 1.1 & $<0.0001$ \\
\hline \multicolumn{5}{|l|}{$\begin{array}{ll}\text { Coronary } & \text { Artery } \\
\text { Disease } & \end{array}$} \\
\hline No & 1.0 & & & \\
\hline Yes & 117.1 & 13.6 & 1011 & $<0.0001$ \\
\hline Blood Urea & 1.8 & 1.4 & 2.4 & $<0.0001$ \\
\hline
\end{tabular}

Given above (Table13) is the multivariate odds ratio with $95 \%$ CI of the statistically significantly contributing variables to the PVD status. One year increase in age among adults $>40$, increased the risk of having PVD by 1.1 times. An adult with diabetic history accessing a general surgery department had 12.8 times more likely to have PVD in reference to a person without history of diabetes. A marked increase in the odds were noticed in the combined variable of hypertension and smoking. Compared to non hypertensive-non smoker, a hypertensivesmoker had 54.5 times and a hypertensive- nonsmoker had 42.7 times more likelihood of having
PVD. A smoking history is confounded by history of hypertension significantly indicative of PVD.

\section{Conclusions}

Prevalence of peripheral vascular disease is about $24.2 \%$ in the present study. This has to be viewed seriously considering the huge type 2 diabetic and hypertensive population. Thus a significant proportion of elderly patients with multiple comorbidities are affected by PVD, and hence due importance to be given for screening and prevention of PVD among these high risk populations. About $69.5 \%$ of the PVD patients are totally asymptomatic and hence the need for active screening with estimation of ABI is to be done annually for all elderly high risk populations. This is important for prevention of lower extremity amputation. Central obesity, uncontrolled diabetes, hypertension, high LDL cholesterol, high triglycerides, low-HDL cholesterol and smoking are the modifiable risk factors associated with development of PVD. Advancing age and male gender were found to be the non modifiable risk factors for development of PVD. Concordance rate for co-morbid CAD was very high $(>70 \%)$ in PVD patients and hence active screening for CAD in all the PVD patients has to be done, even if there is no CAD symptoms. PVD has to be given due importance, and $\mathrm{ABI}$ has to be estimated in all elderly patients, particularly those with high risk life style. Low ABI is associated with cardiovascular complications.

Thus, ABI is a good indicator of underlying complications of diabetes mellitus, particularly CAD. ABI estimation is a non invasive cheap, bedside, and rapid test with a high degree of validity and predictive power and which does not need specially trained persons or costly equipments. Hence, ABI estimation should be done annually for all elderly patients, particularly those with high-risk life style habits for a disease free survival.

\section{References}

1. Feliciano Chanana Paquissi et al. Prevalence of Peripheral Arterial Disease among Adult 
Patients Attending Outpatient Clinic at a General Hospital in South Angola. Scientifica, Volume 2016, Article ID 2520973.

2. Gerald R. Fowkes F, Housley E, Riemersma RA, Macintyre CC, Cawood EH, Prescott RJ, Ruckley CV. Smoking, lipids, glucose intolerance, and blood pressure as risk factors for peripheral atherosclerosis compared with ischemic heart disease in the Edinburgh Artery Study. American journal of epidemiology. 1992 Feb 15;135(4):33140.

3. Hirsch AT, Criqui MH, Treat-Jacobson D, Regensteiner JG, Creager MA, Olin JW, Krook SH, Hunninghake DB, Comerota AJ, Walsh ME, McDermott MM. Peripheral arterial disease detection, awareness, and treatment in primary care. Jama. 2001 Sep 19;286(11):1317-24.

4. Mac Gregor AS, Price JF, Hau CM, Lee AJ, Carson MN, Fowkes FG. Role of systolic blood pressure and plasma triglycerides in diabetic peripheral arterial disease. The Edinburgh Artery Study. Diabetes care. 1999 Mar 1;22(3):453-8.

5. Thomas Manapurathe D, Moxon JV, Krishna SM, Rowbotham S, Quigley F, Jenkins J, Bourke M, Bourke B, Jones RE, Golledge J. Cohort Study Examining the Association Between Blood Pressure and Cardiovascular Events in Patients With Peripheral Artery Disease. Journal of the American Heart Association. 2019 Mar 19;8(6):e010748.

6. Zheng ZJ, Rosamond WD, Chambless LE, Nieto FJ, Barnes RW, Hutchinson RG, Tyroler HA, Heiss G, ARIC Investigators. Lower extremity arterial disease assessed by ankle-brachial index in a middle-aged population of African Americans and whites: the Atherosclerosis Risk in Communities (ARIC) Study. American journal of preventive medicine. 2005 Dec 1;29(5):42-9.
7. Mohan V, Premalatha G, Sastry NG. Peripheral vascular disease in non-insulindependent diabetes mellitus in south India. Diabetes research and clinical practice. 1995 Mar 1;27(3):235-40.

8. Walters DP, Catling W, Mullee MA, Hill $\mathrm{RD}$. The prevalence of diabetic distal sensory neuropathy in an English community. Diabetic Medicine. 1992 May;9(4):349-53.

9. Pendsey S. Peripheral vascular disease $(P V D)$ in diabetics: Indian scenario.Int $\mathrm{J}$ Diabetes DevCtries. 1998;18:31-3.

10. Adler AI, Stevens RJ, Neil A, Stratton IM, Boulton AJ, Holman RR. UKPDS 59: hyperglycemia and other potentially modifiable risk factors for peripheral vascular disease in type 2 diabetes. Diabetes care. 2002 May 1;25(5):894-9.

11. Price J, Mowbray PI, Lee AJ, Rumley A, Lowe GD, Fowkes FG. Relationship between smoking and cardiovascular risk factors in the development of peripheral arterial disease and coronary artery disease; Edinburgh Artery Study: Edinburgh Artery Study. European heart journal. 1999 Mar 1;20(5):344-53.

12. He Y, Jiang Y, Wang J, Fan L, Li X, Hu FB. Prevalence of peripheral arterial disease and its association with smoking in a population-based study in Beijing, China. Journal of vascular surgery. 2006 Aug 1;44(2):333-8.

13. Schaper NC, Nabuurs- Franssen MH, Huijberts MS. Peripheral vascular disease and type 2 diabetes mellitus. Diabetes/metabolism research and reviews. 2000 Sep;16(S1):S11-5.

14. Taylor Jr LM, DeFrang RD, Harris Jr EJ, Porter JM. The association of elevated plasma homocyst (e) ine with progression of symptomatic peripheral arterial disease. Journal of vascular surgery. 1991 Jan 1;13(1):128-36. 
15. Meijer WT, Hoes AW, Rutgers D, Bots ML, Hofman A, Grobbee DE. Peripheral arterial disease in the elderly: the Rotterdam Study. Arteriosclerosis, thrombosis, and vascular biology. 1998 Feb;18(2):185-92. 